\title{
Embryonic development of kidneys in viviparous Typhlonectes compressicauda (Amphibia, Gymnophiona)
}

\author{
Michel Bastit, Jean-Marie Exbrayat* \\ Université de Lyon, Biologie Générale, Université Catholique de Lyon, EPHE Reproduction et Développement Comparé, Lyon, France. \\ * Correspondence: Université de Lyon. UMRS 449. Biologie Générale, Université Catholique de Lyon, EPHE Reproduction et Développement \\ Comparé, 25 rue du Plat, F-69288 Lyon Cedex 02, France. Phone: (33) 472 32 5036, Fax: (33) 47232 50 66. E-mail: jmexbrayat@univ-catholyon.fr
}

Received: 1 February 2011; received in revised form: 24 June 2011; accepted: 13 September 2011.

The embryonic development of organs within Gymnophiona is still poorly known. In Typhlonectes compressicauda, a caecilian amphibian expressing a derived viviparous reproductive mode, development can be divided into 34 stages and is characterized by a metamorphosis occurring between stages 30 and 33. At stages 18-19, Wolffian ducts appear in the anterior part of the embryo. At stage 23, a pair of pronephric kidneys is clearly visible with several nephrostomes that empty into the coelomic cavity. At stage 30, pronephroi that were observed at the level of the second and fifth vertebrae are now observed between the 24 th and 28 th vertebrae. At this stage, several mesonephric tubules appear between the 29th and 32nd vertebrae, and mesonephric tissue is observed in the posterior part of the body. At stage 31, pronephroi begin to disappear. The mesonephroi have now proximal and distal tubules. At stages 32-33, two mesonephroi are visible as a pair of lengthened layers, representing the definitive kidneys.

Key words: Amphibia; development; Gymnophiona; mesonephros; pronephros.

Desarrollo embrionario de los rińones en Typhlonectes compressicauda vivíparas (Amphibia, Gymnophiona). La ontogénesis de los órganos en Gymnophiona es aún poco conocida. En la cecilia vivípara Typhlonectes compressicauda el desarrollo se divide en 34 estadios, y se caracteriza por una metamorfosis que aparece entre los estadios 30 y 33 . Durante los estadios 18-19 los conductos de Wolff aparecen en la parte anterior del embrión. En el estadio 23, se pueden apreciar claramente un par de riñones pronéfricos con varios nefrostomas que vierten a la cavidad celómica. En el estadio 30, los pronefros que antes se podían apreciar al nivel de la segunda y quinta vértebras aparecen ahora entre las vértebras $24^{\mathrm{a}}$ y $28^{\mathrm{a}}$. En este estadio, varios túbulos mesonéfricos aparecen entre las vértebras $29^{\mathrm{a}}$ y $32^{\mathrm{a}}$, mientras que en la parte posterior del cuerpo se puede observar el tejido mesonéfrico. En el estadio 31, el pronefros comienza a desaparecer, mientras que el mesonefros presenta túbulos tanto proximales como distales. En los estadios 32-33, pueden apreciarse dos mesonefros con forma de capas alargadas, en lo que representa los riñones definitivos.

Key words: Amphibia; desarrollo; Gymnophiona; mesonephros; pronephros.

In vertebrates, the development of excretory organs is characterized by the formation of a first pair of primitive kidneys, the pronephroi, situated in the anterior part of the body cavity (BALINSKY, 1975). Behind each pronephros a second type of kidney, the mesonephros, develops generally separated from the pronephros by a space without renal structures. The mesonephros is the definitive kidney in agnates, cartilaginous and bony fishes, and amphibians. The pronephros is characterized by the presence of nephrostomes that connect the nephrons to the coelomic cavity. Each pronephros degenerates during the embryonic development except in some cyclostomes and teleosteans (BRACHET, 1935; BALINSKY, 1975). Wolffian ducts, a pair of primary ureters that collect renal tubules 
from excretory organs, appear in amphibians after the development of pronephroi.

Particularly in amphibians, both open and closed nephrons with or without glomeruli appear in the mesonephros (PORTER, 1972; BALINSKY, 1975). In caecilians (order Gymnophiona), very few works have been devoted to the embryonic development of kidneys. Previous work on this subject has been published by SEMON (1892), who studied the structure and development of urogenital system in Ichthyophis glutinosus, BRAUER (1900, 1902), who investigated kidney development in Hypogeophis sp., and WAKE (1970), who studied the ontogeny of kidneys in embryos of Hypogeophis sp. and Gymnopis multiplicata, as well as the adult kidney of several species. SAKAI et al. (1986) studied the structure and ultrastructure of Typhlonectes compressicauda kidneys, CARVALHO \& JUNQUEIRA (1999) the adult kidneys in Siphonops annulatus, WROBEL \& SÜB (2000) the structure and ultrastructure of Ichthyophis kohtaoensis young larvae kidneys, and MøвJERG et al. (2004) the kidneys of adult Geotrypetes seraphini. Whereas in most amphibians pronephroi degenerate just after the mesonephroi start to function (BALINSKY, 1975), in the studied caecilians it might be possible that pronephroi do not degenerate at this time and that both pro- and mesonephros could form a unique kidney, called holonephros, which would be the supposed primitive situation in vertebrates.

We describe for the first time the development of both pronephroi and mesonephroi in the phylogenetically derived caecilian $T$. compressicauda in order to add data to the knowledge of kidney development in caecilians, to understand the relationships between pronephroi and mesonephroi in basal and derived caecilians, and to understand the evolutionary relationships, based on kidney morphology and ontogeny, between caecilians and other amphibians.

Typhlonetctes compressicauda (Gymnophiona: Typhlonectidae) is a viviparous caecilian amphibian living in South America. The studied specimens live in French Guiana, in swamped areas. Breeding occurs during the rainy season, from December to June, and pregnancy lies until September or October, months when newborn are observed in the field (ExBRAyAT, 1986). The embryonic development has been previously divided in 34 stages (SAmmouri et al., 1990). At the beginning of the development, embryo develops from the yolk mass followed by an intrauterine hatching at stages 25-26. Embryo escapes from the mucous envelope and moves freely in the uterine lumen. Foetal teeth develop on the lower jaw enabling embryo to grasp the uterine secretions and epithelial cells from the uterine wall (Hraoui-Bloquet et al., 1994; HraouiBloquet \& EXbrayat, 1996; EXbrayat \& Hraoui-Bloquet, 2006). Metamorphosis occurs at stages $30-33$, and at that time juveniles resemble adults. Gills develop as a pair of blades surrounding the embryo. Gills are narrowly crushed against the uterine wall, participating to the constitution of a placental structure (HraOUi-Bloquet \& EXBRAyAT, 1994; EXBRAYAT \& HraOUIBLOQUET, 2006).

\section{MATERIALS AND METHODS}

Embryos were obtained from gravid females belonging to a collection of ani- 
mals retrieved from Kaw, a village situated $80 \mathrm{~km}$ southwest of Cayenne, French Guiana, in 1979, 1980 and 1982 (Table 1). Animals were euthanized by immersion in MS 222; embryos at several stages of development were fixed in Bouin's fluid, measured by placing them on graph paper, embedded in paraffin, then sectioned in $5 \mu \mathrm{m}$-thick pieces and stained with haemalum-eosin, Masson-Goldner's trichrome or Romeis's azan in order to obtain several views of morphological structures, according to EXBRAYAT (2001). To prepare the stains, haematoxylin and heamalum were purchased from RAL (Clichy, France), eosin from Acros Organics (Morris Plains, New Jersey, USA), iron alum, acid fuschin and azocarmine G from Sigma-Aldrich (Saint Louis, Missouri, USA), fast green from Edward Gurr (London) and aniline blue from Merck (Whitehouse Station, New Jersey, USA).

Table 1: Length and developmental stage ranges of Typhlonectes compressicauda embryos used for the study of kidney development, according to Sammouri et al. (1990).

\begin{tabular}{ccc}
\hline \hline Developmental stage & Length (mm) & N \\
\hline 18 & Not measured & 1 \\
19 & Not measured & 1 \\
$21-22$ & 7 & 1 \\
23 & $8-10$ & 3 \\
24 & $9-10$ & 5 \\
25 & $10-11$ & 4 \\
$26-27$ & $13-14$ & 3 \\
28 & $18-24$ & 2 \\
29 & $27-30$ & 3 \\
30 & $33-34$ & 2 \\
31 & $37-40$ & 2 \\
32 & $63-70$ & 4 \\
33 & $95-100$ & 2 \\
\hline
\end{tabular}

\section{RESULTS}

At early embryonic stages (18-19), at the level of the fifth somite, in a well anterior position, several undifferentiated cells disposed as a crown are the first indications of the Wolffian ducts (Fig. 1a).

At stages 22-23 (Fig. 1b) certain pronephric tubules are observed laterodorsally to each Wolffian duct. The lumen of the Wolffian duct is lined with a single layer of cubic cells. Several nephrons are observed near the Wolffian ducts, with nephrostomes opening into the coelomic cavity. The lumen of the renal tubules is covered with a single layer of cubic cells without any apical specialization and nephrostomes are lined with a single layer of ciliated cubic cells. In the posterior part, the lumen of the Wolffian duct becomes circular, lined with a single layer of cubic cells. Several flexuous renal tubules develop from Wolffian ducts. Blood cells can agglomerate into a single glomerulus, and several blood vessels are observed near the tubules. This posterior part corresponds to the beginning of mesonephros development (Fig. 1b).

At stage 24 (Figs. 1c, 1d), a pair of pronephroi is observed at the level of the second to the fifth vertebrae. They are composed of well differentiated renal tubules lined with cubic cells containing vacuoles. Two to four nephrostomes open into the coelomic cavity are also observed. Some tubules are wider than others. The widest tubules, corresponding to proximal ones, are lined with cubic cells with abundant cytoplasm, some of which possess an apical brush border directed to the lumen. The narrowest tubules, corresponding to the intermediate and distal ones, are lined with cubic cells, with or without microvilli, whose cytoplasm is 


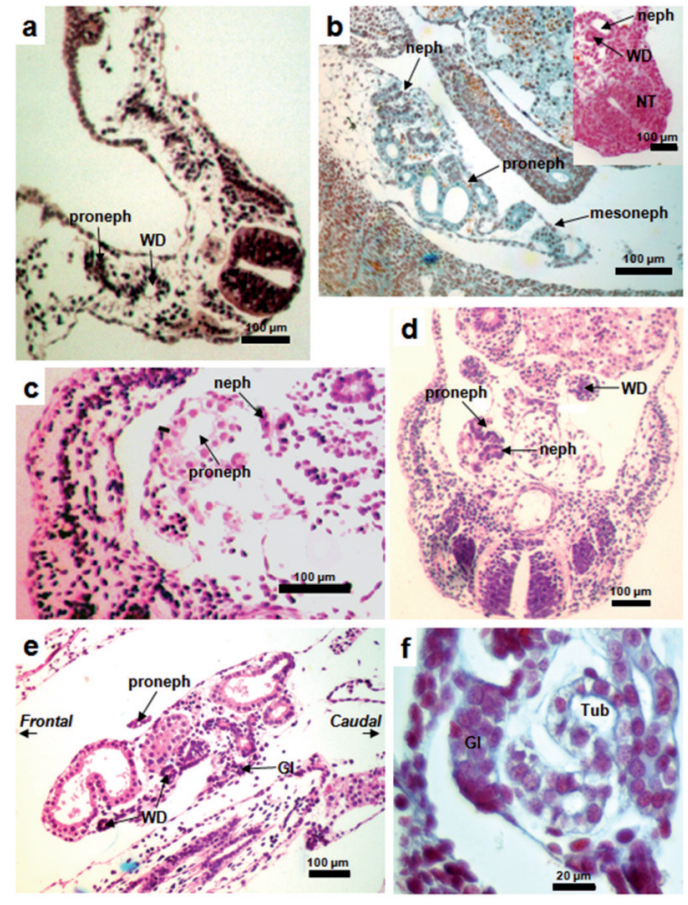

less developed than that of cells lining the widest tubules. Several capillaries extending between tubules can be observed in the pronephros. Capillaries are still not completely built and each one appears as a single cavity filled with blood cells. In the caudal part, the nephric tissue is still not well developed.

At stages 25-26, pronephroi are very well developed with a single glomerulus (Fig. 1e). In the posterior part, nephrons continue to develop, and glomeruli begin to appear (Fig. 1f). Wolffian ducts are lined with a single layer of columnar stereociliated cells.

At stages 27-28, nephrostomes are observed within the pronephroi. Each nephrostome empties into the coelomic cavity (Fig. 2a). Nephrostomes are lined with ciliated cells. Mesonephros is well developed frontally (Fig. $2 b$ ), and continue to develop in the posterior part. The tubules reach the corresponding
Figure 1: Sections of anterior kidney of early embryonic stages of Typhlonectes compressicauda. (a) Stage 19. Cross section stained with haemalum-eosin. (b) Stage 22. Longitudinal section stained with Masson-Goldner's trichrome. The insert shows a cross section stained with haemalum-eosin. (c) (d) Stage 24. Cross sections stained with haemalum-eosin. (e) Stage 26. Longitudinal section stained with haemalumeosin. (f) Stage 26. Longitudinal section stained with Romeis's azan. Gl: glomerulus, mesoneph: mesonephros, neph: nephrostome, NT: neural tube, proneph: pronephros, Tub: renal tubule, WD: Wolffian duct.

Wolffian duct. Renal tubules are lined with brush border cells.

At stage 29, each pronephros is well developed, bearing large nephrons with several capillaries forming a single common ventral Malpighian body. The mesonephros begins to be observed, containing renal tubules with complete nephrons whose glomeruli are more or less developed.

At stage 30, at the beginning of the metamorphosis, all the organs seem to move towards the posterior part of the embryo's body. The heart that was previously observed at the level of the third and fourth vertebrae is now observed at the level of the 23rd and 24 th vertebrae. Both pronephroi and mesonephroi are also displaced. Pronephroi are now observed between the 24th and 28th vertebrae and mesonephroi, situated behind the pronephroi, are observed behind the 29th 
Figure 2: Sections of the anterior kidney of late embryonic stages of Typhlonectes compressicauda stained with Romeis's azan. (a) Stage 27. Longitudinal section showing pronephros. (b) Stage 27. Longitudinal section showing mesonephros. (c) Stage 30. Longitudinal section showing pronephros and mesonephros. (d) Stage 32. Longitudinal section showing mesonephros with a glomerulus. (e) Stage 32. Longitudinal section showing in detail a glomerulus. (f) Stage 33. Longitudinal section. CC: coelomic cavity, Gl: glomerulus, L: liver, Lu: lung, mesoneph: mesonephros, neph: nephrostome, proneph: pronephros, Tub: renal tubule.

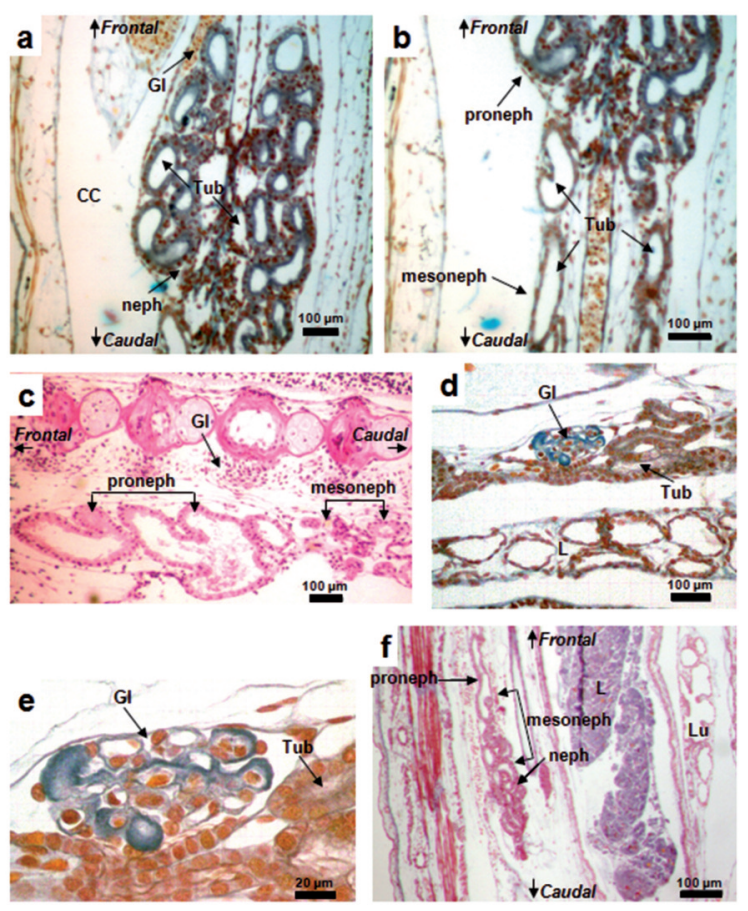

vertebra. The mesonephros is not well separated from the pronephros, and this temporary situation resembles a holonephros (Fig. 2c). The mesonephric nephrons are smaller than the pronephric ones. The posterior part of the mesonephros is still not differentiated.

At stage 31, the nephrostomes decrease in size but their general shape is still recognizable. The pronephros is always observed. The mesonephros continues to develop and appears to be segmented into four masses of tissue. Under the first renal tubules, already developed, new glomeruli are in construction. It is remarkable to note that the anterior part of the mesonephros still contains nephrostomes.

At stage 32 (Fig. 2d), mesonephroi containing voluminous glomeruli (Fig. 2e) appear partially segmented, but at this stage the pronephros is no longer observed. The anterior tip of each kidney is situated at the level of the heart, but it cannot be identified as a pronephros using anatomical and histological criteria because neither open nephrostomes nor wide tubules are observed. The posterior part of the kidneys is almost completely differentiated.

At stage 33 (Fig. 2f), kidneys (mesonephroi) are at the end of their development. They appear as two bands of tissue situated between the heart and the cloaca. In their anterior parts, three or four voluminous nephrons connect to the Wolffian ducts, but it is difficult to recognize them as a pronephros. Nephrons possess now the definitive structure that will be found in adult individuals. Glomeruli are about $90 \mu \mathrm{m}$ in diameter.

In adults, the kidneys (mesonephroi) appear as two parallel bands the tip of them being observed at the level of stomach, clearly well behind the heart, suggesting the degeneration of pronephros. 


\section{DISCUSSION}

For the first time, the development of kidneys has been described in T. compressicauda. Kidneys have been described in several caecilian species (SPENGel, 1876; SEMON, 1892; WiedERSHEIM, 1879; BRAUER, 1902; Brachet, 1935; Chatterjee, 1936; GarG \& Prasad, 1962; WaKe, 1970; SAKai et al., 1986, 1988a,b; CARVAlHo \& JunQUeIRA, 1999; Wrobel \& SÜв, 2000; MøbJERG et al., 2004). In T. compressicauda, the examination of kidney development shows the formation of a pair of pronephroi characterized by nephrostomes, large tubules, and small capillaries irrigating tubules. In Hypogeophis sp., BRAUER (1902) described the presence of very well differentiated nephrostomes throughout both pronephroi and mesonephroi. In this species, eight or nine tubules develop, although 12 tubules can be observed at the initial stages of development. These tubules develop between the 13th and 24th vertebrae, but immediately degenerate. In the posterior part, tubules develop constituting the mesonephros, which is separated from the pronephros. In small I. kohtaoensis larvae studied by Wrobel \& SÜв (2000), a large pronephros is observed caudally to the branchial region, overlapping in its posterior part with the mesonephros.

In embryos of Gymnopis sp. and Hypogeophis sp., WAKE (1970) observed that tubules opened into the coelomic cavity through nephrostomes. Inversely, in adult $S$. annulatus studied by CARVAlHo \& JUNQUEIRA (1999), the kidneys were segmented in the rostral part, with presence of nephrostomes. This situation could indicate the presence of a persistent pronephros in this species, but no ontogenetic study is available in this case. In Hypogeophis sp., pronephroi appear at the level of the fourth somite (BRAUER, 1902; BRACHET, 1935; WAKE, 1970), while in I. kohtaoensis it is located just under the gills (Wrobel \& SÜB, 2000). In I. kohtaoensis (WROBEL \& SÜB, 2000) and Hypogeophis sp. (Brauer, 1902; BRACHET, 1935), Malpighian corpuscle of each pronephros was unique, consisting of a vessel derived from the aorta and divided into several capillaries that occur between tubules, like in T. compressicauda.

After a phase at which pronephroi and mesonephroi are observed together, in a very close position but without overlapping like in I. kohtaoensis (WROBEL \& SÜB, 2000), pronephroi of $T$. compressicauda disappear at metamorphosis. Several nephrostomes can be observed in the anterior part of mesonephroi, like in other caecilians (SPENGEL, 1876; Brauer, 1902; CaRVAlHo \& JUNQUeIra, 1999; MøвJERG et al., 2004). With the exception of T. compressicauda, no information is available on kidney structure during caecilian metamorphosis. In Hypogeophis sp., pronephroi degenerate when mesonephroi become active (BRAUER, 1902; BRACHET, 1935), but authors reporting these findings do not specify if this is coincident with metamorphosis.

In $T$. compressicauda, mesonephroi are segmented in several masses. This situation is different from that of adult G. seraphini, whose mesonephroi are segmented in a frontal position only (MøвJERG et al., 2004). SAKAI et al. (1986, 1988a,b) gave structural and ultrastructural descriptions of adult kidneys in T. compressicauda and observed the presence of several more or less degenerated nephrostomes. Their results are coincident with those of SPENGEL (1876) and BraUER 
(1902) for Hypogeophis sp., or those of MøвJERG et al. (2004) for adult G. seraphini, whose kidneys are long mesonephroi with both ventral tubules open into the coelomic cavity and closed tubules. On the contrary, WAKE (1970) observed numerous adult caecilian species and did not see any nephrostomes open into the coelom.

Several comparative data about embryonic development of kidneys in amphibians have been published (BRACHET, 1935; GipoulouX, 1986; Ditrich \& LAMETSCHWANDTNER, 1992; GiPOULOUX \& CAMBAR, 1995; RiCHTER, 1995; MøBJERG et al., 2000; DraWBridge et al., 2003). Kidneys of caecilians, and particularly of T. compressicauda, possess a lot of common features with the kidneys of both anurans and urodeles (LAMETSCHWANDTNER et al., 1978; SAKAI et al., 1986). Several differences also exist between caecilians and other amphibians. In caecilians, kidneys are elongated like other organs, which is considered to be an adaptation to the burrowing habits of these animals (TAYLOR, 1968). Kidneys of caecilians also present a segmental disposition (WAKE, 1970) that does not exist in anurans or urodeles.

The development of kidneys is similar across all amphibian groups. Pronephroi develop between the third and fourth somites in urodeles, and between the third and fifth somites in anurans. They present nephrostomes that open into the coelomic cavity. Pronephroi are then replaced with functional mesonephroi at metamorphosis (GIPOULOUX, 1986; Gipouloux \& Cambar, 1995). Epithelial cells of the mesonephros first contain osmiophilic granules that disappear at metamorphosis, indicating a change in kid- ney activity at that time (MøBJERG et al., 2000). The ablation of pronephroi in larvae of several anuran species provokes an important oedema followed by death (CAMBAR, 1947), which suggests that these first kidneys are functional at least during a part of larval development. In larval Ambystoma mexicanum, HAUGAN et al. (2010) proposed that pronephroi were important for modification of urine. In Bufo viridis, each pronephros is a single convoluted tubule open into the coelomic cavity through three nephrostomes (MøвJERG et al., 2000), and urine is formed by filtration from an external glomerulus.

In basal caecilians, such as the genus Ichthyophis, pronephroi and mesonephroi overlap, looking like a continuous kidney (SEMON, 1892; Wrobel \& SüB, 2000) and resembling a holonephros, the theoretical primitive kidney of vertebrates. Yet, even in Ichthyophis spp., pronephroi degenerate during development, like in other caecilians such as Hypogeophis sp., Gymnopis sp. (WAKE, 1970), G. seraphini (MøвJERG et al., 2004) and $T$. compressicauda (this work), as well as in anurans and urodeles. In the caecilians whose kidney development has been studied, pronephroi and mesonephroi are separated from each other, either closely or with a large space without any renal formation. These data could be indicating a trend towards the separation of pronephroi and mesonephroi within the order Gymnophiona. Siphonops annulatus can be an exception, as it shows indications of persistent pronephroi in adults (CARVALHO \& JUNQUEIRA, 1999), but no developmental data are available for this species.

In conclusion, the development and structure of T. compressicauda kidneys resemble that of other amphibians (BRACHET, 1935; GIPOULOUX 
\& CAMBAR, 1995), with morphological differences related to burrowing habits. Within caecilians, kidney development and structure of adult kidneys present variations from one species to another. Like other organs, variations could be related to the taxonomic position, with basal Asiatic Ichthyophiidae and American Rhinatrematidae showing pronephros and mesonephros in a closer position than modern taxa such as Typhlonectidae (WILKINSON \& Nussbaum, 2006; EXBRAyAT \& RaQUeT, 2009), and more specifically such as T. compressicauda.

\section{Acknowledgement}

Authors thank Fondation Singer-Polignac who supported collection of animals in French Guiana. Authors also thank Mrs. MarieThérèse Laurent for her technical assistance.

\section{REFERENCES}

BALINSKY, B.I. (1975). Introduction to Embryology, 4th ed. Saunders, Philadelphia, Pennsylvania, USA.

Brachet, A. (1935). Traité d'Embryologie des Vertébrés. Nouvelle Édition Revue et Complétée par A. Dalcq et P. Gérard. Masson et Cie, Paris, France.

Brauer, A. (1900). Zur kenntniss der entwicklung der excretionsorgane der gymnophionen. Zoologischer Anzeiger 23: 353-358.

Brauer, A. (1902). Beiträge zur kenntnis der entwicklung und anatomie der gymnophionen. III. Die entwicklung der excretionsorgane. Zoologisches Jahrbuch für Anatomie 3: 1-176.

CAmbar, R. (1947). Valeur fonctionnelle $\mathrm{du}$ pronéphros chez le très jeune tétard de grenouille. Comptes Rendus des
Scéances de la Société de Biologie et des ses Filiales 141: 754-756.

Carvalho, E.T.C. \& Junqueira, L.C.U. (1999). Histology of the kidney and urinary bladder of Siphonops annulatus (Amphibia-Gymnophiona). Archives of Histology and Cytology 62: 39-45.

ChatTerjee, B.K. (1936) The anatomy of Uraeotyphlus menoni Annandale. Part I. The digestive, circulatory, respiratory, and urino-genital systems. Anatomische Anzeiger 81: 393-414.

Ditrich, H. \& Lametschwandtner, A. (1992). Glomerular development and growth of the renal blood vascular system in Xenopus laevis (Amphibia: Anura: Pipidae) during metamorphic climax. Journal of Morphology 213: 335-340.

DraWbridge, J.; MeIghan, C.M.; LuMPKins, R. \& KiTE, M.E. (2003). Pronephric duct extension in amphibian embryos: migration and other mechanisms. Developmental Dynamics 226: 1-11.

ExBRAyAT, J.-M. (1986). Quelques aspects de la biologie de la reproduction chez Typhlonectes compressicaudus (Duméril et Bibron, 1841), Amphibien Apode. D.Sci. Dissertation. Université Pierre et Marie Curie-Paris 6, Paris, France.

EXBRAYAT, J.-M. (2001). Genome Visualization by Classic Methods in Light Microscopy. CRC Press, Boca Raton, Florida, USA.

Exbrayat, J.-M. \& Hraoui-Bloquet, S. (2006). Viviparity in Typhlonectes compressicauda, In J.-M. Exbrayat (ed.) Reproductive Biology and Phylogeny of Gymnophiona (Caecilians). Series: Reproductive Biology and Phylogeny, vol. 5 (B.G.M Jamieson, ed.) Science Publishers, Enfield, New Hampshire, USA, pp. 325-357. 
Exbrayat, J.-M. \& RaQuet, M. (2009). Vertebrate evolution: the strange case of gymnophionan amphibians, In P. Pontarotti (ed.) Evolutionary Biology: Concept, Modeling and Application. Springer-Verlag, Berlin, Germany, pp. 71-89.

GARG, B.L. \& PRASAD, J. (1962). Observations of the female urogenital organs of limbless amphibians Uraeotyphlus oxyurus. Journal of Animal Morphology and Physiology 9: 154-156.

Gipouloux, J.D. (1986). Prise de forme de l'embryon. Organogenèse. Aspects de physiologie embryonnaire, In P.P. Grassé \& M. Delsol (eds.) Traité de Zoologie, Anatomie, Systématique, Biologie, Tome $X I V$, Fascicule I-B, Amphibiens. Masson, Paris, France, pp. 110-302.

Gipouloux, J.D. \& CAmbar, R. (1995). L'appareil excréteur chez la larve et pendant la métamorphose. In P.P. Grassé \& M. Delsol (eds.) Traité de Zoologie, Anatomie, Systématique, Biologie, Tome XIV, Fascicule I-A, Amphibiens. Masson, Paris, France, pp. 1051-1066.

Haugan, B.M.; Halberg, K.A.; Jespersen, Å.; Prehn, L.R. \& Møbjerg, N. (2010). Functional characterization of the vertebrate primary ureter: structure and ion transport mechanisms of the pronephric duct in axolotl larvae (Amphibia). BMC Developmental Biology 10: 56.

Hraoui-Bloquet, S. \& Exbrayat, J.-M. (1994). Développement des branchies chez les embryons de Typhlonectes compressicaudus, amphibien gymnophione vivipare. Annales des Sciences Naturelles, Zoologie et Biologie Animale, 13 ime Série 15: 33-46.

Hraoui-Bloquet, S. \& Exbrayat, J.-M. (1996). Les dents de Typhlonectes compressicaudus (Amphibia, Gymnophiona) au cours du développement. Annales des Sciences Naturelles, Zoologie, 13 $3^{\text {ime }}$ Série 17: 11-23.

Hraoui-Bloquet, S.; Escudié, G. \& EXBRAYAT, J.-M. (1994). Aspects ultrastructuraux de l'évolution de la muqueuse utérine au cours de la gestation chez Typhlonectes compressicaudus amphibien gymnophione vivipare. Bulletin de la Société Zoologique de France 119: 237-242.

LametschWANDTNer, A.; Albrecht, U. \& ADAM, H. (1978). The vascularization of the kidneys in Bufo bufo (L.), Bombina variegata (L.), Rana ridibunda (L.) and Xenopus laevis (D.) (Amphibia, Anura) as revealed by scanning electron microscopy of vascular corrosion casts. Acta Zoologica 59: 11-23.

Møbjerg, N.; Larsen, E.H. \& Jespersen, Å. (2000). Morphology of the kidney in larvae of Bufo viridis (Amphibia, Anura, Bufonidae). Journal of Morphology 245: 177-195.

Møbjerg, N.; JesPersen, Å. \& Wilkinson, M. (2004). Morphology of the kidney in the West African caecilian, Geotrypetes seraphini (Amphibia Gymnophiona, Caeciliidae). Journal of Morphology 262: 583-607.

PorTer, K.R. (1972). Herpetology. Saunders, Philadelphia, Pennsylvania, USA.

RiCHTER, S. (1995). The opisthonephros of Rana esculenta (Anura). I. Nephron development. Journal of Morphology 226: 173-187.

SAKAI, T.; BILLO, R. \& KRIZ, W. (1986). The structural organization of the kidney of Typhlonectes compressicaudus (Amphibia, Gymnophiona). Anatomy and Embryology 174: 243-252.

SaKai, T.; BILlo, R.; Nobiling, R.; Gorgas, K. \& KRIZ, W. (1988a). Ultrastructure of the kidney of a South American caecilian, Typhonectes compressicaudus (Amphibia, Gymnophiona). I. Renal corpuscle, neck segment, proximal tubule and intermediate seg- 
ment. Cell and Tissue Research 252: 589-600. SaKaI, T.; Billo, R. \& Kriz, W. (1988b).

Ultrastructure of the kidney of a South American caecilian, Typhonectes compressicaudus (Amphibia, Gymnophiona). II. Distal tubule, connecting tubule, collecting duct and Wolffian duct. Cell and Tissue Research 252: 601-610.

SAmmouri, R.; Renous, S.; Exbrayat, J.-M. \& LesCuRE, J. (1990). Développement embryonnaire de Typhlonectes compressicaudus (Amphibia, Gymnophiona). Annales des Sciences Naturelles, Zoologie, 13 ime Série 11: 135-163.

SEMON, R. (1892). Studien über den bauplan des urogenitalsystems der wirbeltiere. Dargelegt an der entwicklung dieses organsystems bei Ichthyophis glutinosus. Jenaische Zeitschrift für Naturwissenschaft 26: 89-203.

SPENGEL, J.W. (1876). Das urogenitalsystem der amphibien. I. Theil. Der anatomische bau des urogenitalsystems. Arbeit aus dem
Zoologisch-Zootomischen Institut in Würzburg 3: 1-114.

TAYLOR, E.H. (1968). The Caecilians of the World: A Taxonomic Review. University of Kansas Press, Lawrence, Kansas, USA. WAKE, M.H. (1970). Evolutionary morphology of the caecilian urogenital system. Part II. The kidney and the urogenital ducts. Acta Anatomica 75: 321-358.

WiedersheIM, R. (1879). Die anatomie der gymnophionen. Gustav Fisher, Jena, Germany. WilkINSON, M. \& NusSBAUM, R.A. (2006). Caecilian phylogeny and classification, In J.M. Exbrayat (ed.) Reproductive Biology and Phylogeny of Gymnophiona (Caecilians). Series: Reproductive Biology and Phylogeny, vol. 5 (B.G.M Jamieson, ed.). Science Publishers, Enfield, New Hampshire, USA, pp. 39-78.

Wrobel, K.-H. \& SÜB, F. (2000). The significance of rudimentary nephrostomial tubules for the origin of the vertebrate gonad. Anatomy and Embryology 201: 273-290. 